\title{
Ajwa Improves Nicotine Induced Ovarian Toxicity in Murine Model \\ ${ }^{1}$ Faeza Rauf, ${ }^{2}$ Muhammad Suhail, ${ }^{2}$ Tayyaba Muzaffar, ${ }^{2}$ Javaid Iqbal, ${ }^{3}$ Sadia Iqbal, ${ }^{4}$ Asia Nazeer \\ ${ }^{1}$ Department of Anatomy, Azra Naheed Medical College, Lahore \\ ${ }^{2}$ Department of Anatomy, Shaikh Zayed Medical Complex, Lahore \\ ${ }^{3}$ Department of Anatomy, Quaid e Azam Medical College, Bahawalpur \\ ${ }^{4}$ Department of Anatomy, Amna Inayat Medical College, Sheikhupura
}

\begin{abstract}
Introduction: Nicotine, a major component of cigarette smoke, alters ovarian function and Ajwa (Phoenix dactylifera) being an antioxidant prevents its toxicity. Aims \& Objectives: This experimental study was designed to evaluate protective effect of Ajwa against ovarian toxicity induced by nicotine in adult albino rats. Place and duration of study: The study was conducted in the Department of Anatomy, Federal Postgraduate Medical Institute, Shaikh Zayed Medical Complex, Lahore for duration of 3 months (January 2017-March 2017). Material \& Methods: 40 adult female albino rats were divided into four equal groups. $1 \mathrm{ml}$ distilled water was given to the rats of control (A) group by gastric intubation, experimental group B was given nicotine injection intraperitoneally $(0.1 \mathrm{mg} / \mathrm{kg}$ body weight $)$ for 28 days. The rats of experimental group C were given Ajwa fruit extract $1 \mathrm{gm} / \mathrm{kg}$ body weight daily by gastric intubation, while rats of experimental group D were given $0.1 \mathrm{mg} / \mathrm{kg}$ body weight nicotine intraperitoneally plus $1 \mathrm{gm} / \mathrm{kg}$ body weight Ajwa fruit extract by gastric intubation for 28 days. Results: In group B, secondary and Graafian follicles were mostly atrophic, degeneration of granulosa cells, pyknotic nuclei and stromal vacuolization were present. Zona pellucida was torn and irregular. Mean diameters of secondary and Graafian follicles were significantly lower in nicotine group B ( $\mathrm{p}$-value $<0-001^{*}$ ). Experimental group $\mathrm{C}$ revealed normal histological architecture and diameter of ovarian follicles. Near normal restoration of follicular structure was seen in group D. Conclusion: Ajwa fruit extract is counterbalancing for nicotine induced oxidative stress in ovarian follicles of rat, so it may be useful to improve infertility or sub-fertility induced by smoking in females.
\end{abstract}

Key words: Ajwa, Nicotine, Ovarian toxicity, Phoenix dactylifera

\section{INTRODUCTION}

$\mathrm{S}_{\mathrm{m}}$ respiratory, and reproductive system. ${ }^{1}$ Over the past few years, incidence of smoking has increased among women of reproductive age. In women, smoking is associated with low fertility rates, menstrual abnormalities, ectopic pregnancies, spontaneous abortion, and early onset of menopause. ${ }^{2}$

Nicotine, major constituent $(50-90 \%)$ of tobacco smoke, is an alkaloid form of pyridine and pyrrolidine rings, also found in green pepper, potato and tomato. It is responsible for addiction. Freely available formulations are cigarettes, topical patches, nicotine gums and nasal spray. Every cigarette contains $10-14 \mathrm{mg}$ of nicotine. Nicotine can actively pass through all biological membranes and can be absorbed through lungs, skin, oral mucosa, and gut. ${ }^{3}$

Intraperitoneal administrations of nicotine are more effective than the oral route because it facilitates the rapid absorption of the substance. Bioavailability of nicotine in intraperitoneal route is about $100 \%{ }^{4}$ About 70 to $80 \%$ of nicotine in humans is converted to cotinine. ${ }^{1}$ Cotinine, detected in the follicular fluid and granulosa lutein cells of smoker women, create a poisonous atmosphere for follicular development and oocyte maturation. It also inhibits the release of gonadotropins from the pituitary gland by affecting the central nervous system. ${ }^{5}$

Ajwa (Phoenix dactylifera) belongs to family Arecaceae. "Phoenix dactylifera" means red or purple finger-like fruit bunch appearance. ${ }^{6}$ The Saying of Holy Prophet Mohammad (PBUH) is“" One who eats 7 dates every morning, will be 
protected from poison or magic on that day, he eats them." "7

Ajwa dates contain at least six vitamins including vitamin $\mathrm{A}, \mathrm{B}_{1}, \mathrm{~B}_{2}, \mathrm{C}$ and nicotinic acid. Aqueous extract of Ajwa dates has higher concentration of polyphenols including p-coumaric, ferulic and sinapic acids, flavonoids and procyanidins. Ajwa dates maintain the highest antioxidant activity among other types of dates. ${ }^{8}$ It significantly inhibits protein oxidation and lipid peroxidation and has a radical scavenging activity for hydroxyl and superoxide. Antioxidants act together and neutralize free radicals and stop them from producing damage. ${ }^{9}$

Ajwa dates aqueous extract improved spermatogenesis, as well as remarkably enhanced the testicular structure against ochratoxin A induced testicular damage and can be used for the treatment of sexual impairment and male infertility. ${ }^{10}$ So this study was designed to evaluate protective effect of Ajwa against ovarian toxicity induced by nicotine in adult albino rats.

\section{MATERIAL AND METHODS}

After the approval of institutional review board, this randomized controlled trial was conducted in the Department of Anatomy, Federal Post graduate Medical Institute, Lahore in collaboration with Department of Anatomy, Punjab PGMI, Lahore. 40 adult healthy female albino rats aged 3-4 month (average body weight 200-250 gm) were kept at $23 \pm 2^{\circ} \mathrm{C}$ and a 12 hour light and dark cycle was maintained. They were fed on normal food and given water ad libitum. They were acclimatized for a period of two weeks before the experiment started. Ajwa Dates were purchased from Madinah AlMonawarah and their extract was prepared by following method. ${ }^{11}$

3000 gram of date fruits were separated by hand from pits and 1 liter distilled water was added to this crudely crushed date fruit $(3: 1)$. This was left for 48 hours in freezer $\left(4^{\circ} \mathrm{C}\right)$ with occasional stirring. This aqueous extract of Ajwa contains Phenolic content (1.752 mg Gallic Acid Equivalent /g of extract) and Flavonoid Content (0.1239 mg Quercetin equivalent/g of extract) quantified by Chemistry Department, PCSIR, Lahore. Nicotine synthesis grade (99\% pure) loose liquid Fluka, was purchased from local market.

The animals were randomly divided into four groups by lottery method, each containing ten animals.
Control group A: Rats were treated with $1 \mathrm{ml} / \mathrm{kg}$ body weight (b.w) of distilled water by gastric intubation for 28 days.

Experimental group B: Nicotine was given $0.1 \mathrm{mg} / \mathrm{kg}$ b.w/day intraperitoneally for 28 days.

Experimental group C: Rats received Ajwa fruit extract $1 \mathrm{~g} / \mathrm{kg}$ b.w/day by gastric intubation for 28 days.

Experimental group D: Each rat was given nicotine $0.1 \mathrm{mg} / \mathrm{kg}$ b.w/day intraperitoneally and Ajwa fruit extract $1 \mathrm{~g} / \mathrm{kg}$ b.w by gastric intubation for 28 days.

48 hours after giving the last dose, rats in estrous phase were dissected. Other rats were left till their estrous phase. Rats were humanly sacrificed by using intraperitoneal administration of morphine at a dose of $0.3-0.5 \mathrm{mg} / \mathrm{kg}$ and the ovaries were dissected out, kept in $10 \%$ neutral buffered formaldehyde solution for 48 hours. Small pieces were cut and paraffin blocks were made. Serial sections of $5 \mu \mathrm{m}$ thickness were taken. Hematoxylin and Eosin stained follicles were observed under the light microscope and labeled according to standard classification by Tober Pederson and Peters. ${ }^{12}$ Based on Gougeon's criteria; all follicles were concurrently assessed for morphological signs of atresia. $^{13}$

Diameters of ovarian follicles were calculated by taking horizontal and vertical measurements at right angle to each other and taking their average, the mean diameter of each of ovarian follicle was multiplied with calibration factor. Four follicles were used from each slide and ten slides from each animal using objective power $10 \mathrm{x}$. Comparison was made between control group $\mathrm{A}$ and experimental groups $\mathrm{B}, \mathrm{C}$ and $\mathrm{D}$.

\section{Statistical Analysis:}

Data was entered and evaluated by using Statistical Package for Social Sciences (SPSS), version 20. Data for qualitative variables (histology of primordial, secondary and Graafian follicles) was described by using frequency and percentage of each group. Comparison among groups was made by using Chi-square/Fisher's exact test. Diameter of secondary and Graafian follicles was described as mean \pm S.D and comparison among groups was performed by using ANOVA (one way).For post hoc analysis, Tukey's test was used where necessary. P-value $\leq 0.05$ was considered significant. 


\section{RESULTS}

In control group, ovary was surrounded by simple cuboidal surface epithelium lie on top of a layer of dense connective tissue capsule. Follicles were fixed in connective tissue stroma of cortex. Medulla, the center of ovary was made up of loose connective tissue, blood vessels, nerves and lymph vessels. Theca interna and externa cells, granulosa cells and corpus luteum showed normal histological features. In control and experimental groups, capsule and primordial follicles were found to be normal (Fig-1). In all four groups, connective tissue capsule was almost of same thickness, $10 \mu \mathrm{m}$, only one rat of group B had $15 \mu \mathrm{m}$ thickness of capsule, which was not statistically significant.

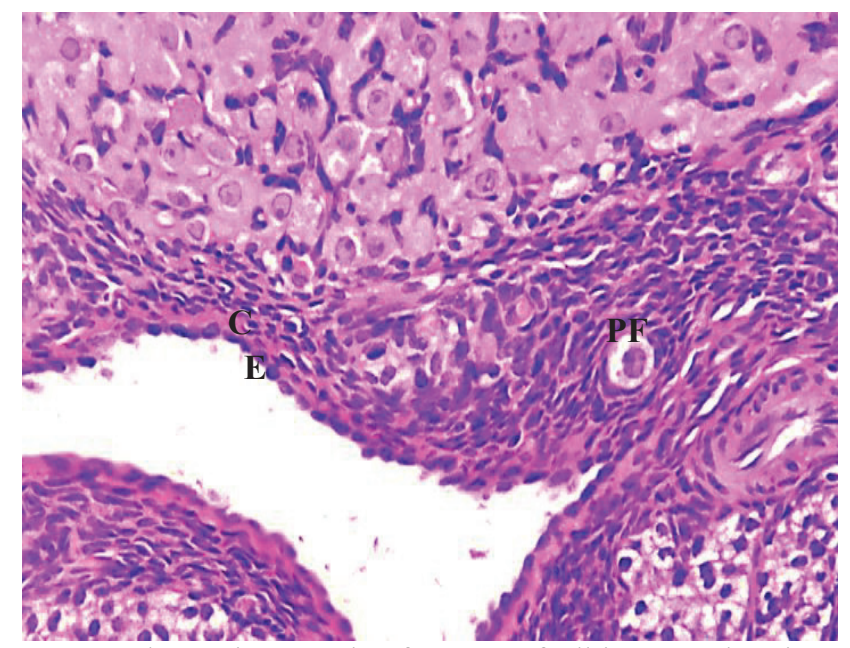

Fig-1: Photomicrograph of ovary of albino rat showing normal simple cuboidal Epithelium (E), Capsule (C), Primordial Follicle (PF). (H \& E, 40X)

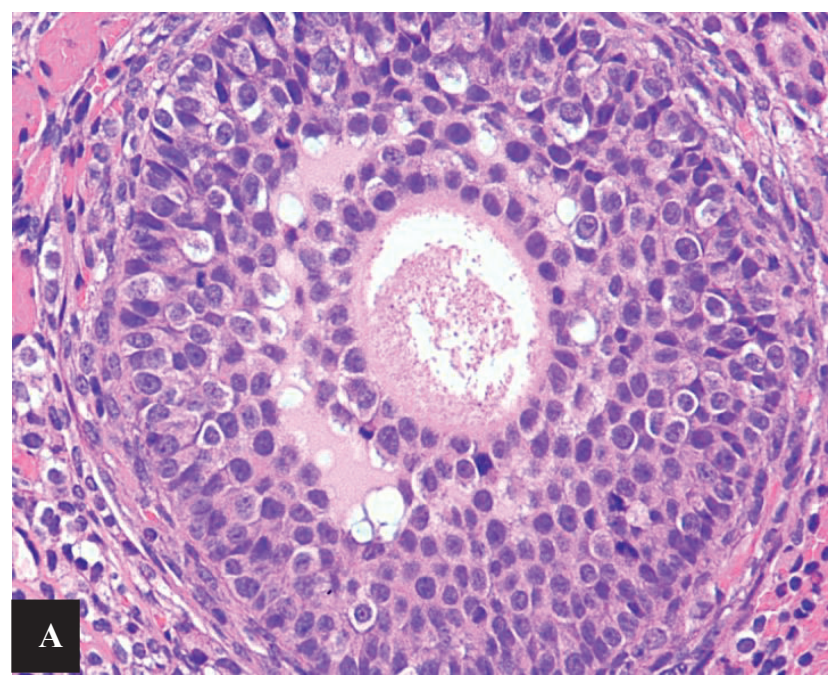

Fig-2A: Photomicrograph showing normal structure of secondary follicle of Control group A (H\&E,20x)

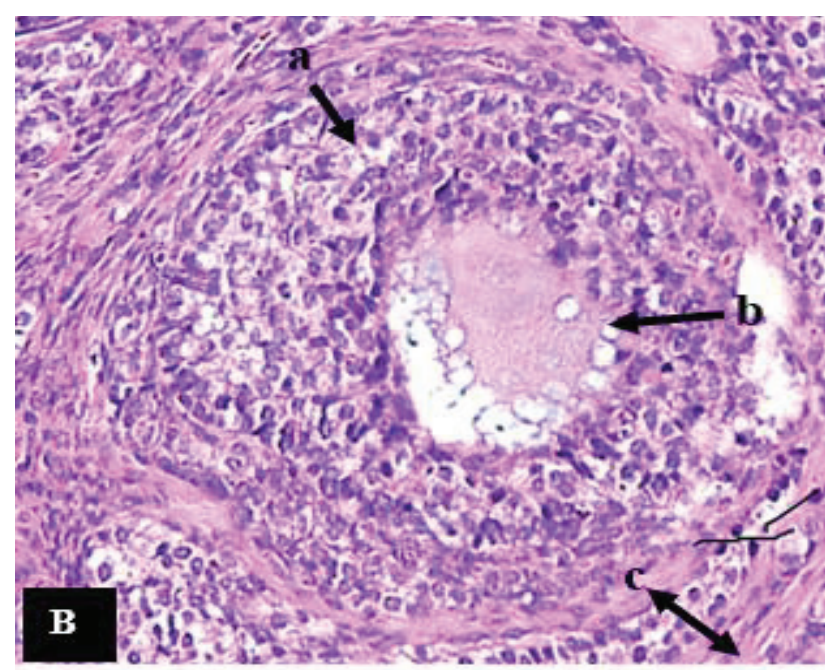

Fig-2B: Smaller sized secondary follicle showing pyknosis (a), vacuolization (b), fibrosis in theca interna and irregular zona pellucida (c).

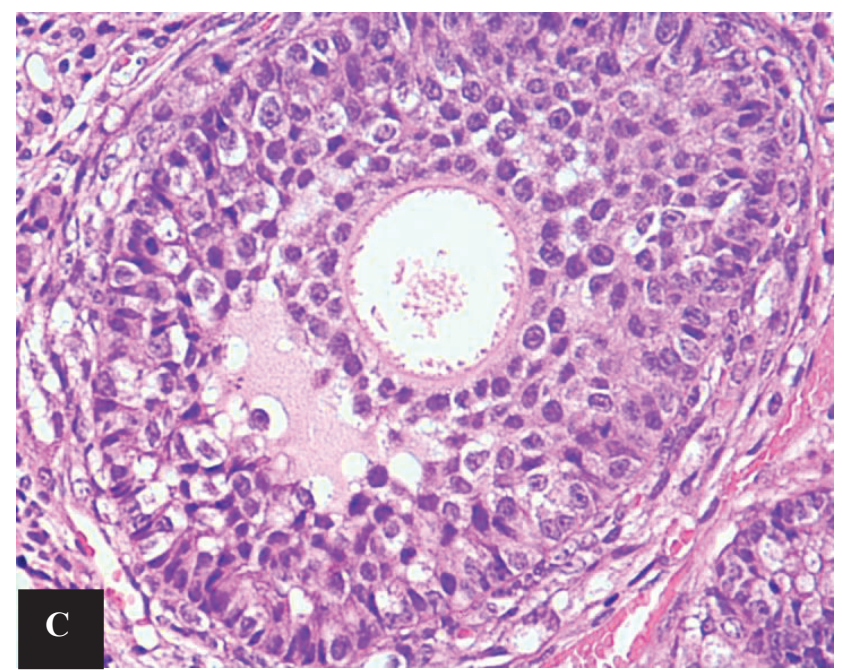

Fig-2C: Secondary follicle of rat experimental group C showing normal structure (H\&E, 20x).

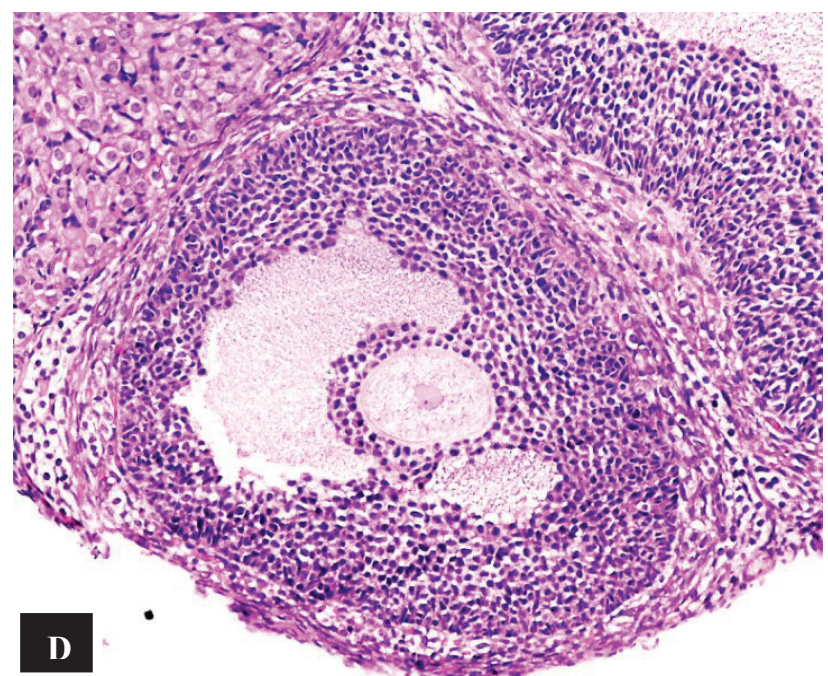

Fig-2D: Secondary follicle of rat experimental group D showing normal structure (H\&E, 10x). 
Secondary follicles were lodging in deeper part of cortical stroma in control group A and experimental group $\mathrm{C}$, revealed normal histological architecture (Fig-2A\&2C). In experimental group B, the size of secondary follicles was relatively decreased as compared to control group. Number of atrophic follicles was increased. Oocytes were non-spherical, zona pellucida was torn and irregular. Degeneration of granulosa cells of ovarian follicles was seen. Many degenerated cells were seen in antrum. Nuclei were crescent shaped, pyknotic, fragmentation and stromal vacuolization was present (Fig-2B). In experimental group $\mathrm{D}$, shape and size of follicles were restored to near normal. (Fig-2D). Distribution of appearance of Secondary follicle among control $\&$ experimental groups is shown in Table-1.

\begin{tabular}{|c|c|c|c|c|c|}
\hline $\begin{array}{c}\text { Secondary } \\
\text { follicle }\end{array}$ & $\begin{array}{c}\text { Group A } \\
\mathbf{n}(\%)\end{array}$ & $\begin{array}{c}\text { Group B } \\
\mathbf{n}(\%)\end{array}$ & $\begin{array}{c}\text { Group C C } \\
\mathbf{n}(\%)\end{array}$ & $\begin{array}{c}\text { Group D } \\
\mathbf{n}(\%)\end{array}$ & p-value \\
\hline Normal & 10 & 0 & 10 & 8 \\
$(100.0 \%)$ & $(0.00 \%)$ & $(100.0 \%)$ & $(80.0 \%)$ & \multirow{2}{*}{$<0.001 *$} \\
\cline { 1 - 4 } Abnormal & $\begin{array}{c}0 \\
(0.0 \%)\end{array}$ & $\begin{array}{c}10 \\
(100.0 \%)\end{array}$ & $\begin{array}{c}0 \\
(0.0 \%)\end{array}$ & $\begin{array}{c}2 \\
(20.0 \%)\end{array}$ & \\
\hline
\end{tabular}

Table-1: Distribution of appearance of Secondary follicle among control \& experimental groups. Based on Fisher's exact test

Secondary follicles of group B showed significant changes as compared to groups A, C \& D. Pairwise comparison of appearance of secondary follicle revealed that difference of group A from group B as shown in Table-2. Diameter of secondary follicle among groups are compared in Table-3.

\begin{tabular}{|c|c|c|c|c|}
\hline \multicolumn{2}{|c|}{ Group } & Chi-square & Df & p-value \\
\hline \multirow{2}{*}{$\mathrm{A}$} & $\mathrm{B}$ & 20.00 & 1 & $<0.001^{*}$ \\
\cline { 2 - 5 } & $\mathrm{C}$ & - & - & - \\
\cline { 2 - 5 } & $\mathrm{D}$ & 2.22 & 1 & 0.474 \\
\hline \multirow{2}{*}{$\mathrm{B}$} & $\mathrm{C}$ & 20.00 & 1 & $<0.001^{*}$ \\
\cline { 2 - 5 } & $\mathrm{D}$ & 1.333 & 1 & $0.001^{*}$ \\
\hline $\mathrm{C}$ & $\mathrm{D}$ & 2.22 & 1 & 0.474 \\
\hline
\end{tabular}

Table-2: Multiple Comparisons for Secondary follicle among the Groups. $(*$ p value $\leq 0.05$ considered statistically significant, df Degree of freedom Non calculable being constant)

\begin{tabular}{|l|c|c|c|c|c|}
\hline Parameters & $\begin{array}{c}\text { Group } \\
\text { A }\end{array}$ & $\begin{array}{c}\text { Group } \\
\text { B }\end{array}$ & $\begin{array}{c}\text { Group } \\
\text { C }\end{array}$ & $\begin{array}{c}\text { Group } \\
\text { D }\end{array}$ & p-value \\
\hline $\begin{array}{l}\text { Diameter of } \\
\text { secondary } \\
\text { follicle }(\mu \mathrm{m})\end{array}$ & 372.5 & 255.7 & 370.5 & 369.5 & $<0.001 *$ \\
\hline
\end{tabular}

Table-3: Comparison of diameter of secondary follicle among groups based on one way ANOVA.
Post hoc Tukey test was used for multiple comparison, it showed that diameter of secondary follicle in group B was significantly lower as compared to remaining all groups. The difference of group $\mathrm{B}$ from group $\mathrm{C}$ and $\mathrm{D}$ was also highly significant with p-values 0.001 and 0.002 . However, no significant difference was found in the diameter of secondary follicle among groups A, C and D (Fig-3).

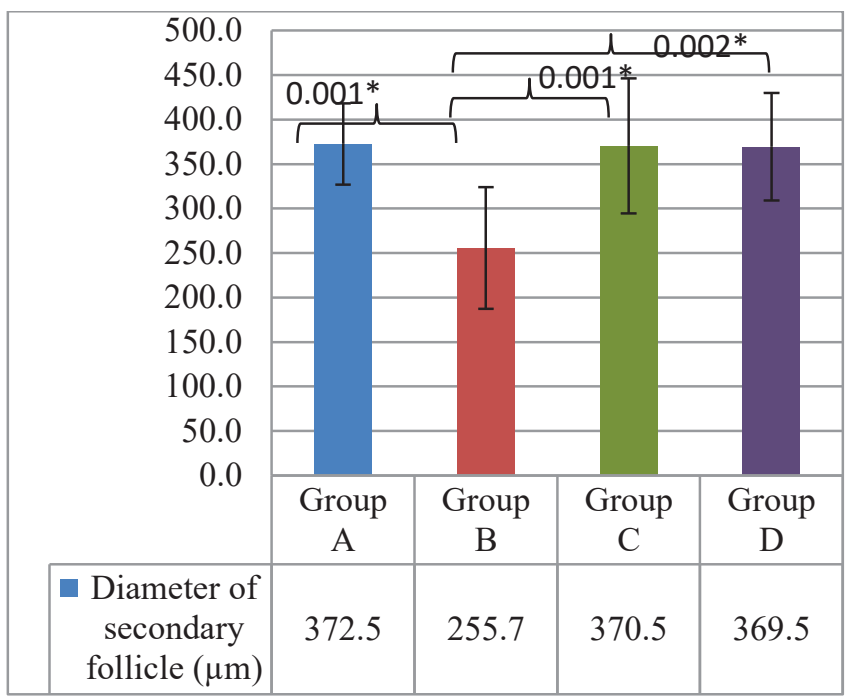

Fig-3: Bar chart showing comparison of diameters of secondary follicles $(\mu \mathrm{m})$ among different groups.

The Graafian follicles were present near surface of ovary and occupied larger part of cortex in groups A, B, C \& D. Normal structure of Graafian follicle was seen in control group $\mathrm{A}$ and experimental group C. (Fig-4A \& 4C)

In experimental group B, majority of Graafian follicles were atrophic. Oocyte was absent with edema and congestion in the surrounding cells. Zona pellucida was torn and irregular. Degeneration and detachment of granulosa cells was seen (Fig-4B). Macrophages, neutrophils, fibroblasts and lymphocytes were present. Follicular cysts were also seen. In experimental group $\mathrm{D}$, shape and size of Graafian follicle was restored to near normal and atrophic changes were reduced. (Fig-4D)

\begin{tabular}{|c|c|c|c|c|c|}
\hline $\begin{array}{c}\text { Graafian } \\
\text { follicle }\end{array}$ & $\begin{array}{c}\text { Group A } \\
\text { n (\%) }\end{array}$ & $\begin{array}{c}\text { Group B } \\
\text { n (\%) }\end{array}$ & $\begin{array}{c}\text { Group C } \\
\text { n (\%) }\end{array}$ & $\begin{array}{c}\text { Group D } \\
\text { n (\%) }\end{array}$ & $\begin{array}{c}\text { p- } \\
\text { value }\end{array}$ \\
\hline Normal & 10 & 0 & 10 & 7 & \\
& $100.0 \%)$ & $(0.0 \%)$ & $(100.0 \%)$ & $(70.0 \%)$ & 0.001 \\
\hline Abnormal & $\begin{array}{c}0 \\
(0.0 \%)\end{array}$ & $\begin{array}{c}10 \\
(100.0 \%)\end{array}$ & $\begin{array}{c}0 \\
(0.0 \%)\end{array}$ & $\begin{array}{c}3 \\
(30.0 \%)\end{array}$ & \\
\hline
\end{tabular}

Table-4: Distribution of appearance of Graafian follicle among control \& experimental groups based on Fisher's exact test. 


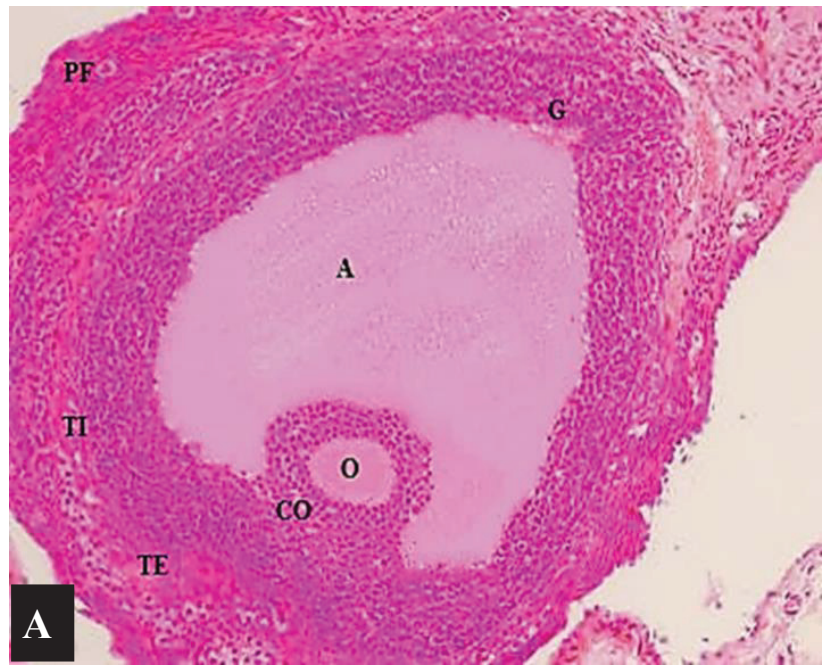

Fig-4A: Showing normal Graafian follicle of control group A. (H\&E, 20x).

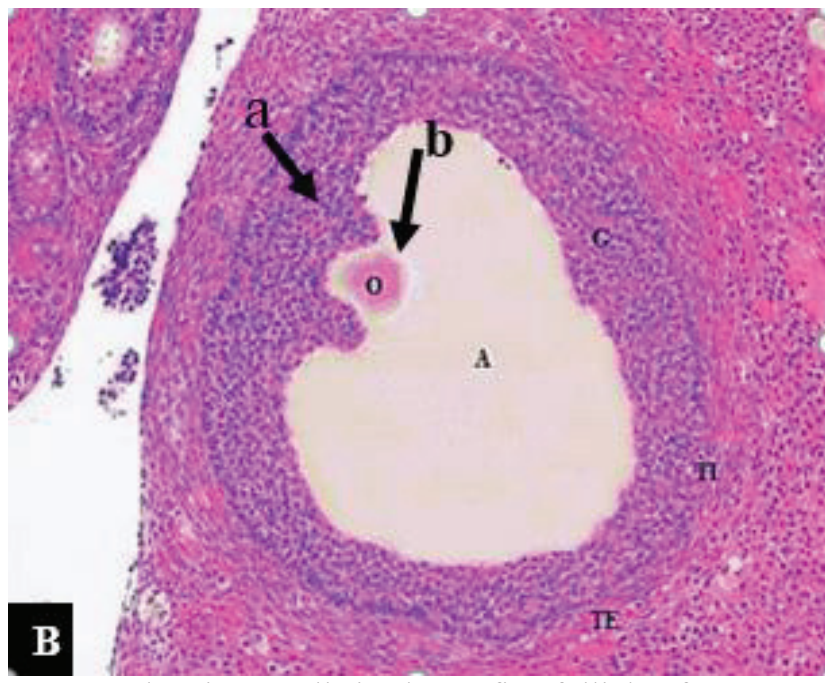

Fig-4B: Showing small sized Graafian follicle of group B with pyknosis (a) torn zona pellucida (b).(H\&E,20x)

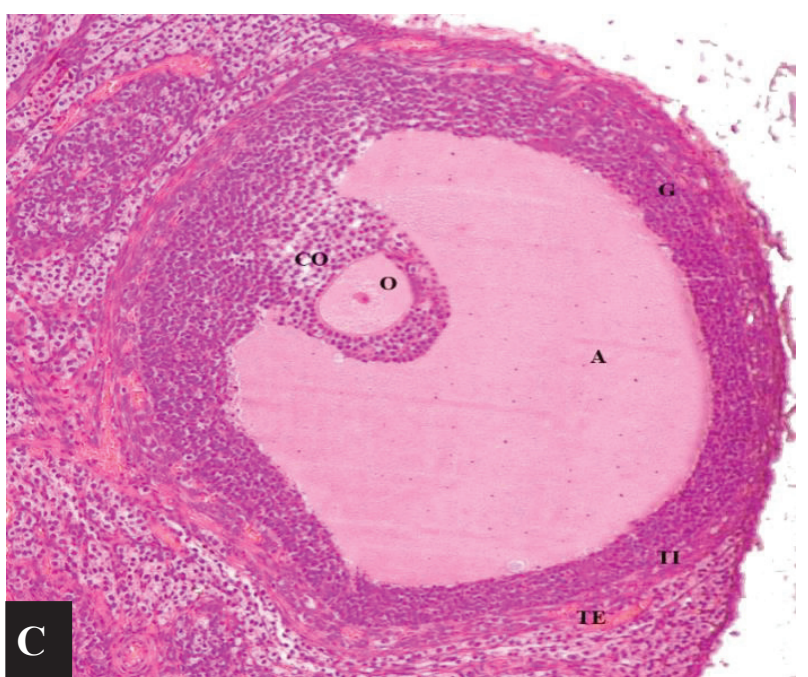

Fig-4C: Graafian follicle of rat experimental group C showing normal structure, Antrum (A), Ovum (O), Zona Granulosa (G), Theca Interna (TI), Theca Externa (TE).(H \& E at 20x)

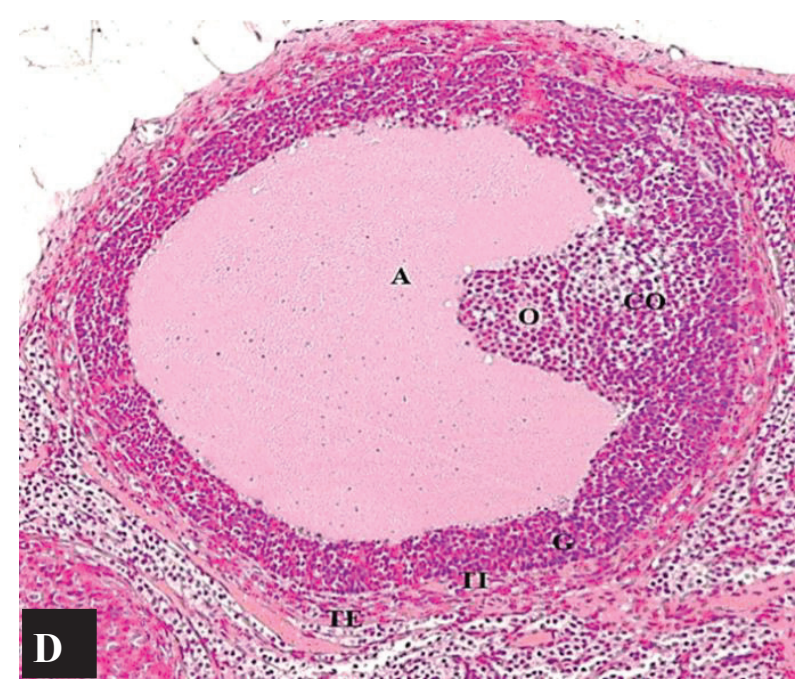

Fig-4D: Graafian follicle of rat experimental group D showing normal structure, Antrum (A), Ovum (O), Zona Granulosa (G), Theca Interna (TI), Theca Externa (TE). (H \& E at 20x)

\begin{tabular}{|c|c|c|c|c|}
\hline \multicolumn{2}{|c|}{ Group } & Chi-square & df & p-value \\
\hline \multirow{3}{*}{$\mathrm{A}$} & $\mathrm{B}$ & 20.00 & 1 & $<0.001^{*}$ \\
\cline { 2 - 5 } & $\mathrm{C}$ & - & - & - \\
\cline { 2 - 5 } & $\mathrm{D}$ & 3.53 & 1 & 0.211 \\
\hline \multirow{2}{*}{$\mathrm{B}$} & $\mathrm{C}$ & 20.00 & 1 & $<0.001^{*}$ \\
\cline { 2 - 5 } & $\mathrm{D}$ & 10.77 & 1 & $0.003^{*}$ \\
\hline $\mathrm{C}$ & $\mathrm{D}$ & 3.53 & 1 & 0.211 \\
\hline
\end{tabular}

Table-5: Multiple comparisons for Graafian follicle among the groups. $(* \mathrm{p}$ value $\leq 0.05$ is considered statistically significant, - Non calculable being constant)

One way ANOVA test was applied to compare the diameter of Graafian follicle among groups. It was found that the mean diameter of Graafian follicle in all groups were significantly different, p-value < 0.001. (Table-6).

\begin{tabular}{|l|c|c|c|c|c|}
\hline Parameters & $\begin{array}{c}\text { Group } \\
\text { A }\end{array}$ & $\begin{array}{c}\text { Group } \\
\text { B }\end{array}$ & $\begin{array}{c}\text { Group } \\
\text { C }\end{array}$ & $\begin{array}{c}\text { Group } \\
\text { D }\end{array}$ & $\begin{array}{c}\text { p- } \\
\text { value }\end{array}$ \\
\hline Diameter of & 571.0 & $404.0 \pm$ & $573.0 \pm$ & $566.0 \pm$ & $<$ \\
Graafian & $\begin{array}{c}51.9 \\
\text { follicle } \mu \mathrm{m}\end{array}$ & 61.1 & 52.9 & 55.2 & $0.001 *$ \\
\hline
\end{tabular}

Table-6: Comparison of diameter of Graafian follicle among groups based on one way ANOVA.

Post hoc Tukey test showed that diameter of Graafian follicle in group B was significantly lower as compared to remaining all groups. Difference of group $\mathrm{A}$ and group $\mathrm{B}$ was significant with $\mathrm{p}$ value $<0.001 *$. Comparing group $\mathrm{B}$ with group $\mathrm{C} \&$ D showed statistically significant difference with $\mathrm{p}$ value $<0.001^{*}$. However, no significant difference was found in the diameter of Graafian follicle among groups A, C and D (Table-6, Fig-5). 


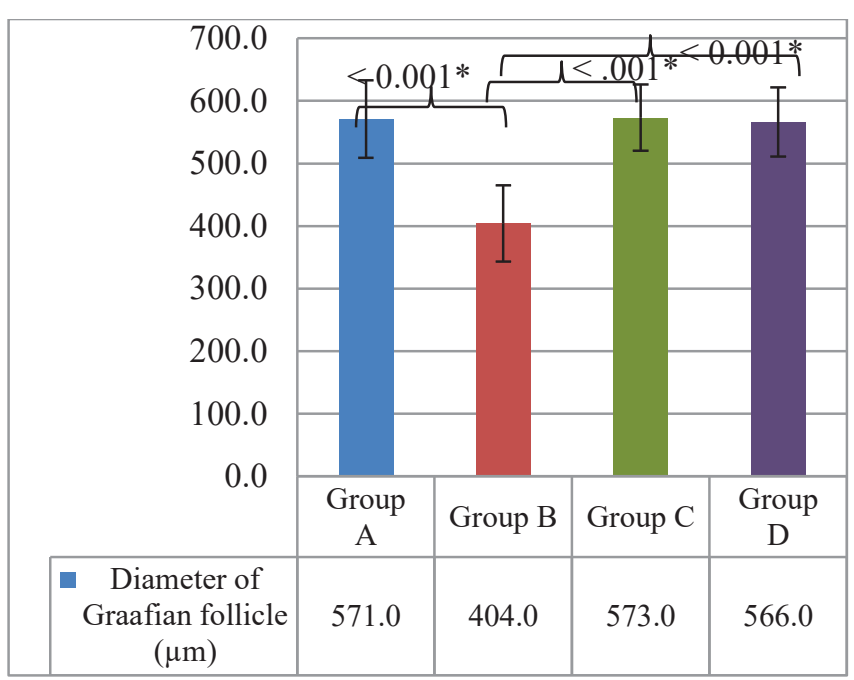

Fig-5: Bar chart showing comparison of diameter of Graafian follicle $(\mu \mathrm{m})$ among groups.

\section{DISCUSSION}

The maximum introduction of nicotine is through active smoking via cigarette, pipe or cigar and next is the environmental tobacco smoke - passive smoking. Smoking reduces fertility and mature follicles in ovary. ${ }^{14}$ Phoenix dactylifera has been used as an essential food for centuries in the Arab countries. Dates are used as a tonic in medicinal practice, potentially safe and has been used to improve fertility in females.

Nicotine at given dose does not cause any change in primordial follicles. So in all four groups, primordial follicles were normal. Similarly, connective tissue capsule was almost of same thickness $10 \mu \mathrm{m}$, only one rat of B group had $15 \mu \mathrm{m}$ thickness of capsule, which was not statistically significant. These results coincide with results of Ghasemi et $a{ }^{15}$ in his study all follicles were affected except primordial follicle.

In animals of group B, secondary and Graafian follicles were more affected than any other type of follicles due to increased effect of nicotine on granulosa cells which are much more in large follicles than in smaller ones. Nicotine acetylcholine receptors nAChR-2 and nAChRs-7 have been recognized on granulosa cells. ${ }^{16}$ Nicotine activate caspase 3 in different tissues through nAChR-2 and nAChRs-7, causes apoptosis in granulosa cells and atrophy of secondary and Graafian follicles. Nicotine also negatively affects primary follicle decreasing ovulation. ${ }^{17,18}$

In nicotine treated group, toxic effects on granulosa cell function or aromatase activity reflects decreased estrogen levels. ${ }^{15}$ Tuttle noted that cigarette smoke is a renowned reproductive toxicant linked with ovarian failure and causes follicle loss in mice ovaries without affecting ovulation at concentrations characteristic of human exposure. ${ }^{19}$ In contrast Galam et $\mathrm{al}^{20}$ stated that nicotine causes $\mathrm{LH}$ independent inhibition of ovulation in immature gonadotrophin stimulated rats. Nicotine decreases estrogen level, prevents initiation of progesterone production in cumulus cells by FSH and synthesis of androgen by theca interna cells. ${ }^{17}$ Estrogen acts via FSH receptors, stimulates the proliferation of granulosa cells and promotes follicular development. So in nicotine treated rats proliferation of granulosa cells may change. However, Petrik et $a{ }^{16}$ did not find anti proliferative activity of nicotine on granulosa cells.

In secondary and Graafian follicles of group B nuclei were crescent shaped, pyknotic, fragmentation, vacuolization was evident. Mature follicles were without oocytes, ooplasm was present, congestion, edema was seen around the vessels. Follicular cysts were also seen. These results coincide with results reported by Syna et al. ${ }^{21}$ Desquamation of granulosa cells inside the antral cavity and irregular zona pellucida around the oocytes were present. In nicotine treated group vacuoles were inside granulosa layers. Apoptic changes in granulosa cells were also seen by Juriscova et al. ${ }^{22}$ Nicotine affects central nervous system and inhibit gonadotropin release from pituitary. In ovary nicotine administration alters concentration of steroid hormone, causes irregularities in estrous cycle, impaired ovulation, reduces number and size of secondary follicle, Graafian follicles and corpora lutea and increases number of atrophic follicles as seen in research by Tuttle et al. ${ }^{19}$

Reducing the Graffian follicle diameter decreases the size of the ovarian cortex which ultimately affects the whole ovary. On the other hand, the evolutionary process of follicles is controlled by hypothalamic-pituitary-ovary axis secretion. Therefore, the secretion of this axis also changes the development of follicles. Nicotine can act directly on ovarian morphology. Ghasemi ${ }^{15}$ reported that study done by Patil et al showed reduced number of healthy follicles and improved number of atretic follicles in the ovary of nicotine treated rats. Since steroids are necessary for growth and progress of female generative organs, the degeneration in the ovary was due to inhibition of steroidogenesis by pituitary gonadotrophins in nicotine treated rats which lowered glycogen content and raised ovarian cholesterol level. Nicotine will either inhibit estrogen production or the capability of estrogen to control follicular development thus the delayed in ovulation following nicotine administration reported 
by Iranloye and Bolarinwa. ${ }^{23}$ Reduced estrogen synthesis prolonged metaestrus and diestrus and reduced number of estrus cycles. ${ }^{24}$

In Ajwa treated group, number and size of follicles increased. Capsule was intact. Corpus luteum was good, normal looking, eosinophilic and vesicular. Vessels showed no congestion. Primordial follicles were well formed. In secondary follicles antrum was well formed. Graafian follicles increased in size and well formed with intact oocytes, granulosa cells and cumulous oophorous. These results coincide with results of Ali and Abdu, ${ }^{25}$ they observed that Ajwa date extract preserved the kidney architecture. These results also coincide with results of Moshfegh et $\mathrm{al}^{26}$ where date palm pollen consumption lead to increase in diameter of embryonic ovary and increase in basic sexual cell counts in female embryo.

In Ajwa plus nicotine treated group, capsule of ovary was intact and of same size as in animals of control group, little or no congestion of blood vessels. Primordial follicles were normal, secondary follicles were atrophic in two out of ten rats. Three Graafian follicles were seen with atrophic changes and seven were normal. In this study cortex of ovary was normal. These results restored ovarian morphology and coincide with results of Ali and $\mathrm{Abdu}^{25}$ where Ajwa extract restored renal morphology after mycotoxin alteration. Similarly, administration of melatonin protected folliculogenesis in ovary in nicotine treated rats in a study by Ghasemiet al. ${ }^{15}$ In a study by Saeed et al, ${ }^{27}$ nicotine induced spermatotoxicity was reversed by date palm pit powder. Administration of goat milk (antioxidant action) given to nicotine treated mice increased weight of testis and reversed the toxic effects on affected seminiferous tubules in a study by Anum et al. $^{28}$ Green tea administration to nicotine treated rats improved spermatogenesis in a study by Gawish et al. ${ }^{29}$

The present study shows poisonous effects of nicotine on ovaries of adult albino rats, nicotine increased atrophic follicles, it also caused vacuolation of follicular cells and congestion of medullary blood vessels. It was concluded that nicotine causes oxidative stress affecting growing follicles, maturation of follicles, and decreased ovulation. Histological analysis of the ovaries from rats of experimental group D receiving Ajwa fruit extract and nicotine showed that Ajwa fruit extract has ameliorated the histopathological lesions remarkably and highly improved folliculogenesis (Fig-2D, 4D) partly through effect on hypothalamopituitary gonadal axis. Shape of ovaries is preserved; results of group D coincides with results of $\mathrm{Abdu} \mathrm{SB}^{30}$ where Ajwa dates had protective and ameliorative influence against ochratoxin $\mathrm{A}$ induced testicular damage.

The present study highlights the awareness to change towards the use of natural medicinal foodstuff and states the defensive abilities of the aqueous extract of Ajwa fruit on nicotine-induced ovarian damage in rats.

\section{CONCLUSION}

Ajwa fruit extract is counterbalancing for nicotine induced oxidative stress in ovarian follicles of rat, so it may be useful to improve infertility or subfertility induced by smoking in females.

\section{REFERENCES}

1. Mishra A, Chaturvedi P, Datta S, Sinukumar S, Joshi P, Garg A. Harmful effects of nicotine. Indian Journal of Medical and Paediatric Oncology: official journal of Indian Society of Medical \& Paediatric Oncology. 2015; 36(1):24.

2. Dechanet C, Anahory T, Mathieu DJC, Quantin X, Refytmann L, Hamamah S, Hedon B, Dechaud H. Effects of cigarette smoking on reproduction. Hum Reprod. 2010: 17(1):76-95.

3. Moerke MJ, McMahon LR, Wilkerson JL. More than Smoke and Patches: The quest for pharmacotherapies to treat tobacco use disorder. Pharmacological Reviews. 2020; 72(2): 527-57.

4. Proctor HDC, Kulasekaran A,Malmqvist, Richter A. Determination of nicotine absorption from multiple tobacco products and nicotine gum. Nico Tobac Res. 2013; 15(1):255-61.

5. Oyeyemi WA, Kolawole TA, Shittu ST, Ajah R, Oyeyemi BF. Effects of ascorbic acid on reproductive functions of male Wistar rats exposed to nicotine. Journal of African Association of Physiological Sciences. 2014; 2(2):110-6.

6. Al-Turki SM. Antioxidant properties of date palm (Phoenix dactylifera L.) cultivars. Colorado State University; 2008.

7. Saafi EB, Louedi M, Elfeki A, Zakhama A, Najjar MF, Hammami M, Achour L. Protective effect of date palm fruit extract (Phoenix dactylifera L.) on dimethoate induced-oxidative stress in rat liver. Experimental and Toxicologic Pathology. 2011 Jul 1; 63(5):433-41.

8. Rahmani AH, Aly SM, Ali H, Babiker AY, Srikar S. Therapeutic effects of date fruits (Phoenix dactylifera) in the prevention of diseases via modulation of anti-inflammatory, anti-oxidant and anti-tumour activity. 
International journal of clinical and experimental medicine. 2014; 7(3):483.

9. El Arem A, Saafi EB, Lahouar L, Thouri A, Ghrairi F, Achour L. Date palm fruit extract attenuated oxidative stress induced by two haloacetic acids in Wistar rats. Mediterranean Journal of Nutrition and Metabolism. 2017; 10(2): 141-52.

10. Abdu SB. Ameliorative influence of ajwa dates on ochratoxin A-induced testis toxicity. J Microsc Ultrastruct. 2018; 6:134-8.

11. Ali A and Abdu S. Antioxidant protection against pathological mycotoxins alterations on proximal tubules in rat kidney. Func Foods in Heals \&Diseas. 2011; 4: 118-134.

12. Myers M, Britt KL, Wreford NG, Ebling FJ, Kerr JB. Methods for quantifying follicular numbers within the mouse ovary. Reproduction. 2004 May 1; 127(5):569-80.

13. Fleming R, Seifer DB, Frattarelli JL, Ruman J. Assessing ovarian response: antral follicle count versus anti-Müllerian hormone. Reproductive biomedicine online. 2015 Oct 1; 31(4):486-96.

14. Camlin NJ, Sobinoff AP, Sutherland JM, Beckett EL, Jarnicki AG, Vanders RL, Hansbro PM, McLaughlin EA, Holt JE. Maternal smoke exposure impairs the long-term fertility of female offspring in a murine model. Biology of reproduction. 2016; 94(2): 39-1.

15. Muhammad Ghasemi F, Khajeh J S, Haji zadeh H, Homafar, M A, Saadat N. Protective effect of exogenous melatonin on nicotine induced changes in mouse ovarian follicles. J Reprod Infertil. 2012; 13(3):143-150.

16. Fan G, Zhang Q, Wan Y, Lv F, Chen Y, Ni Y, Zou W, Zhang W, Wang H. Decreased levels of $\mathrm{H} 3 \mathrm{~K} 9 \mathrm{ac}$ and $\mathrm{H} 3 \mathrm{~K} 27 \mathrm{ac}$ in the promotor region of ovarian P450 aromatase mediated low estradiol synthesis in female offspring rats induced by prenatal nicotine exposure as well as in human granulosa cells after nicotine treatment. Food and Chemical Toxicology. 2019; 128:256-66.

17. Bordel R, Laschke MW, Menger MD, Vollmar B. Nicotinedoes not affect vascularization but inhibits growth of freely transplanted ovarian follicles byinducing granulosa cell apoptosis. Hum Reprod. 2006; 21(3):610-7.

18. Audi SS, Abrahan ME, Broker AS. Effect of cigarette smoke on body weight, food intake and reproductive organs in adult albino rats. Ind J Exp Biol. 2006; 44:562-5.

19. Tuttle AM, Stämpfli M, Foster WG. Cigarette smoke causes follicle loss in mice ovaries at concentrations representative of human exposure. Hum Reprod. 2009; 24(6):1452-9.
20. Galam NZ, Gambo IM, Galam ZZ, Dami GS, Raymond VA, Egesie UG et al. The Effect of Varied Doses of Nicotine on Some Morphometric Parameters of the Testis in Albino Wistar Rats. Journal of Natural Sciences Research. 2013; 7(3): 187-91.

21. Syna PS, Afroz SK, Usha I. Histological analysis of effects of smokeless tobacco on the ovaries of the nonpregnant female swiss albino rats. Int J Sci Eng Res. 2014; 5:4.

22. Juriscova A, Taniuchi A, Li H, Shang Y, Antenos M, Detmar J, Matikainen T, Benito Hernandez A, Nunez G et al. Maternal exposure to polycyclic aromatic hydrocarbons diminishes murine ovarian reserve via induction of Harkiri. J Clin Inv. 2007; 117: 3971-3978

23. Iranloye BO, Bolarinwa AF. Effect of nicotine administration on weight and histology of some vital visceral organs in female albino rats. Niger J Physiol Sci. 2009; 24(1):7-12.

24. Patil S, Patil SR, Bhaktaraj B, Patil SB. Effect of graded doses of nicotine on ovarian and uterine activities in albino rats. Ind J Exp Biol. 1999; 37:184-6

25. Ali A and Abdu S. Antioxidant protection against pathological mycotoxins alterations on proximal tubules in rat kidney. Func Foods in Heals \& Diseas. 2011; 4: 118-134.

26. Moshfegh F, Baharara J, Namvar F, ZafarBalanezhad S, Amini E, Jafferzadeh L et al. Effect of date palm pollen on fertility and development of reproductive system in female balb/c mice. JMP. 2016; 5(1):23-28.

27. Saeed K, Tahir M, Lone KP. Effect of Phoenix dactylifera (date palm) pit powder on nicotine induced spermatotoxicity in adult albino rats. JPMA. 2015; 65-43.

28. Anum FA, Hashida NH, Mahanem MN. Preliminary Study on the Effect of C Administration of Goat Milk and Nicotine on Rat Sperm Parameters. Repro Biotechnicol. 2010; 7: 44-5.

29. Gawish AM, Ramadan S, Hassan A, Mlssa AM. Morphometrical, Histopathological and Cytogenetical ameliorating effects of Green tea extract on Nicotine toxicity of the Testis of Rats. J Am Sci. 2010; 6:401-11.

30. Abdu SB. Ameliorative influence of ajwa dates on ochratoxin A-induced testis toxicity. J Microsc Ultrastruct. 2018; 6(3): 134. 
The Authors:

Dr. Faeza Rauf

Assistant Professor

Department of Anatomy,

Azra Naheed Medical College, Lahore.

Prof. Muhammad Suhail

Head, Department of Anatomy,

Shaikh Zayed Medical Complex, Lahore.

Dr. Tayyaba Muzaffar

Assistant Professor,

Department of Anatomy,

Shaikh Zayed Medical Complex, Lahore.

Dr. Javaid Iqbal

Associate Professor,

Department of Anatomy,

Shaikh Zayed Medical Complex, Lahore.
Dr. Sadia Iqbal

Senior Demonstrator,

Department of Anatomy,

Quaid-e-Azam Medical College, Bahawalpur.

\section{Dr. Asia Nazeer}

Senior Demonstrator,

Department of Anatomy,

Amna Inayat Medical College, Sheikhupura.

\section{Corresponding Author:}

Dr. Faeza Rauf

Assistant Professor,

Department of Anatomy,

Azra Naheed Medical College, Lahore

E mail: rauf.faeza@gmail.com 